Indonesian Science Education Research

(ISER)

Available online https://jurnal.unimed.ac.id/2012/index.php/iser

ISSN Online: 2715-4653

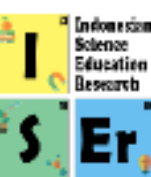

\title{
QUANTITATIF ANALYSIS OF THE 2013 CURRICULUM OF PHYSICS TEXT BOOK USING SCIENCE INSTRUMENTS TEXTBOOK RATING SYSTEM LABORATORY
}

\author{
${ }^{1}$ Fatihah Suci S. A. J., Zeni Haryanto, and Muliati Syam \\ Department of Physic Education, Universitas Mulawarman, Samarinda, Indonesia \\ fatihahsucisajannah@gmail.com
}

Accepted: December $5^{\text {th }}, 2020$. Published: December $31^{\text {th }}, 2020$

\begin{abstract}
This study aims to: (1) describe the suitability of the textbooks for XI grade high school students in Physics under curriculum 2013 program based on the criteria that refer to STRS, spesifically at the aspects of laboratory activities (2) describe the quality of textbooks for XI grade high school students, curriculum 2013 based on the criteria that refer to STRS, specifically in laboratory aspects. This study is a descriptive study with an evaluative approach that describes the contents of the book. This study describes the quality of the Physics textbook for XI grade students curriculum 2013 published by a private or non-BSE at the aspect of laboratory activities. To collect the data, the researcher used the STRS modified by Septiana Karumaningrum as the instrument. The results of this study indicated that (1) this book has a suitability level of $78 \%$ based on the criteria that refer to STRS, spesifically in the aspects of laboratory activities. (2) this book has a good quality (B) based on the criteria that refer to STRS, spesifically in laboratory aspects.
\end{abstract}

Keywords: Analysis, Textbooks, STRS, Laboratory Activities. 


\section{Introduction}

Physics lessons must be presented in their entirety so that in addition to being able to understand scientific facts, students are also able to understand and live up to scientific values which will be manifested in scientific attitudes and behavior. In order for this to be realized, students must be actively involved in scientific processes while learning physics takes place. This is also related to the understanding of physics as a whole, namely, physics is an attempt to find something with a scientific attitude and method. So, in this case, physics learning has the ability to be able to explore the secrets of nature and its regular patterns. If then all of this can be done well when learning physics, then students will be able to become a generation that acts as a problem solver for any existing problems, both now and problems that will come.

regarding to that, national education functions to develop and shape a dignified national character and civilization in order to educate the nation's life. In the world of education at the school level, textbooks are present as a means of helping to realize these expectations. The available textbooks should focus more on reasoning so that students are expected to be able to understand and master concepts. These concepts can be applied creatively to be able to solve real problems that exist in everyday life.

Regulation of the Minister of Education and Culture of the Republic of Indonesia Number 8 of 2016 concerning books used by education units, states that textbooks are mandatory reference books for use in schools that contain subject matter in order to increase faith and piety, character and personality, mastery ability science and technology, sensitivity and aesthetic abilities, physical potential and health which are compiled based on National Education Standards. Based on this, good quality textbooks will result in a good learning process and results.

Textbooks are written materials in the form of sheets and bound which contain knowledge derived from the basic competencies in the applicable curriculum for later use by students (Lestari, 2013).

A wide variety of textbooks are widely available on the market from private publishers, including physics textbooks for high school / equivalent. The more books that are circulating, the selection of books must also be done carefully. Related to this, the role of teachers and students in selecting textbooks for the learning process is needed.

Indonesia is currently implementing the 2013 curriculum as a reference in preparing learning programs, the BSE physics senior high school curriculum 2013 book has also existed and has been assessed by BNSP to be later designated as a book worthy of circulation and can be used by students and teachers in the learning process. However, it does not rule out the public also choose to use privately published books as a learning resource. As in interviews that have been conducted in several schools in Samarinda, although in schools students are provided with LKS but there are several schools that use BSE physics textbooks, there are also schools that choose to use non-BSE textbooks as companion books as a reference in implementing the process. Learning.

International scale book assessment for science subjects such as the Science Textbook Rating System (STRS) instrument by Collete and Chiapetta in his book entitled Science Instruction in the Middle and Secondary Schools, while for the national scale it is BSNP. In the Science Textbook Rating System (STRS) the criteria for book assessment include content, book organization, readability, understanding of concepts and principles, instructional approaches, illustrations, learning assistance at the end of each chapter, laboratory activities, assistance for teachers, index and glossary and physical appearance of the text book.

Satiti (2019) quotes Geene and Petty's statement in Muslich (2010: 53) that one of the categories that quality textbooks must fulfill is that they can attract students who use them. One aspect that can attract students in learning textbooks is the existence of laboratory activities or experiments in addition to attracting students' interest in learning, laboratory activities can help students to understand the concepts and principles of physics 
appropriately.

The results of previous research were carried out by comparing BSE and Non BSE books. KTSP has differences in quality from the criteria in STRS, in the laboratory aspect the highest score is owned by non-BSE books, so it is necessary to do textbook analysis research in 2013 curriculum physics subjects.

The questions that arise in this study are (1) "Does the textbook for high school physics class XI curriculum 2013 have conformity based on the criteria that refer to STRS, especially in the aspect of laboratory activities?" (2) "How is the quality of the textbooks for high school physics subject class XI in the 2013 curriculum based on the criteria that refer to STRS, especially in the laboratory aspect?".

\section{Research Method}

The type of research conducted in this research was content analysis research using an evaluative approach that seeks to describe. This study describes the quality of high school physics textbook class XI 2013 curriculum published by a private non-BSE on the aspect of laboratory activities.

The population in this study were all high school physics text books class XI 2013 curriculum published by private non-BSE. The sample in this study was a physics textbook for Senior High School class XI, curriculum 2013, published by a private nonBSE on any material that includes laboratory activities. The book that have been analyzed was the Senior High School class XI Physics book by Bambang Ruwanto, Yudisthira publisher.

Sampling was done by purposive sampling. Purposive sampling is also called judgmental sampling, which is sampling based on "judgment" or deliberate sampling in accordance with the required sample requirements and a senior high school class XI Physics book by Bambang Ruwanto, Yudisthira publisher, was selected on each material that included laboratory activities.

The data was collected using the STRS instrument by Collette \& Chiapetta (1994) which has been modified by Septiana Karumaningrum which has been validated by the expert judgment of lecturers (Physics Education FMIPA UNY).

The data analysis and hypotheses carried out in this study were to obtain a score from the coding result set for each criterion which then added up the score, in order to obtain a total score of the aspect assessment with a maximum score of 50 and a minimum score of 10

\begin{tabular}{lll}
\hline Num & Range of Value & Score Category \\
\hline $\mathbf{1}$ & $10-20$ & D (Bad) \\
$\mathbf{2}$ & $21-30$ & C (Enough) \\
$\mathbf{3}$ & $31-40$ & B (Good) \\
$\mathbf{4}$ & $41-50$ & A (Very Good) \\
\hline
\end{tabular}

From the total score, it was then be analyzed and then the quality profile of each book studied will be obtained. To show the suitability percentage of the textbook, the following equation was used:

percentage $=\frac{\text { score summary }}{\text { score maximum }} \times 100 \%$

\section{Result and Discussion}

\section{Result}

After conducting an assessment of the research sample by the researcher, the results of the assessment of aspects of laboratory activities are obtained as follows:

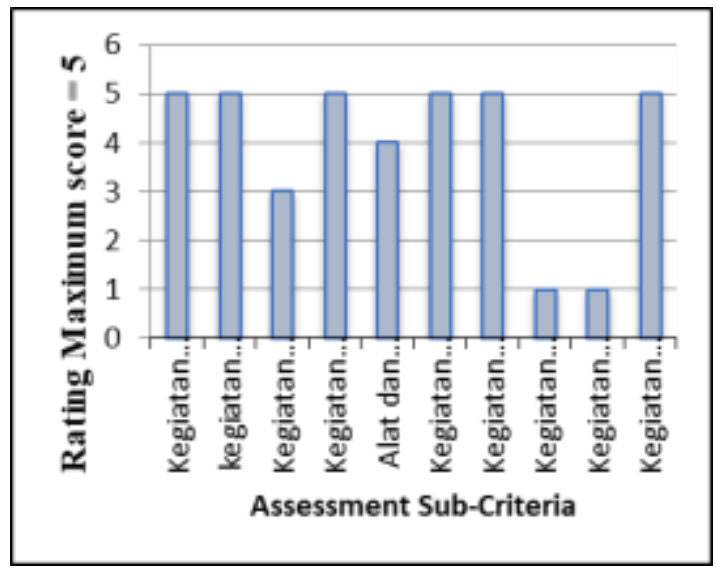

Figure 1. Result of Assessment of Laboratory Activity Aspects

The results of the analysis of the assessment of aspects of laboratory activities on the subject of textbooks in physics subject for class XI of the 2013 non-BSE curriculum published by a private sector obtained a total score of 39, thus the book was a book categorized as good (B) in the aspect under 
study, namely aspects of laboratory activities. Then the book has a conformity rate of $78 \%$.

\section{Discussion}

The purpose of this research was to describe the quality of the physics textbook for Senior high school students class XI Curriculum 2013 through quantitative content analysis. The book under study is a book by Bambang Ruwanto. This book is included in both (B) with a total score of 39 in terms of the aspect of laboratory activities. This book consists of 21 experiments.

In Chapter 1, the Dynamics of Rotation and Firmness of the Balance consists of 3 experiments. The first experiment the author lists on pages 12-13 was the moment of inertia. The experimental (laboratory) activities presented by the author aim to understand the magnitude of the moment of inertia through simple experiments. After conducting the experiment the students were able to find out what quantities worked at the moment of inertia. The writer presents this activity by emphasizing the investigative aspect and can be carried out during the class using a pen or pencil that is rotated on a different axis. A clear and sequential work procedure is presented with points, the author also includes a picture of the experiment so that students will find it easy to carry out experiments.

The second experiment the author lists on pages 17-18 regarding the moment of force. This experiment aims to understand the magnitude of the force moment through a simple experiment. This experiment was carried out using a door in the room, some suction rubber and a spring balance, where the author emphasizes the investigative aspect and can be carried out during the teaching and learning process in the classroom. The experimental procedure is arranged in detail starting from the process of observing and collecting data, in this process there are two variables that are carried out, namely the variation in the position of the suction rubber on the door against the hinge and the angle variation on the hinge which affects the amount of force applied, the author also includes a picture of the experiment to be carried out. , thus making it easy for students to carry out these experiments. After that students are asked to reason and communicate the results of the experiments they have done.

The third experiment the author lists on page 36 regarding determining the center of gravity of objects. The author does not include the purpose of doing the experiment. The tools and materials as well as the author's work procedures present in detail so that it makes it easier for students to carry out experiments, besides that the author also includes an experimental image so that students get instructions other than the work procedure for conducting experiments.

Chapter 2 Elasticity and Hooke's Law consists of 3 experiments. The first experiment the author lists on page 59 regarding the elasticity and plasticity experiments. The purpose of this experiment is to observe plastic materials. The tools and materials are presented clearly, the tools and materials used are simple, so that students can complete the experiment during the learning process. The work procedure displayed is also presented systematically, students will observe the plastic bag that is loaded with stones (weights) and not.

The second experiment the authors list on pages 64-65 regarding spring elasticity. This experimental activity aims to determine the relationship between the magnitude of the force and the increase in the length of the spring. The author includes tools and materials as well as a series of experiments so that students can easily experiment. The author's experimental procedure is presented in the form of points so that students will find it easy to follow step by step in conducting experiments. In this experiment the writer also presents an observation table to make it easier for students to retrieve and analyze data. In addition, the authors also include a graph after the experiment was carried out.

The third experiment the author lists on pages 68-69 regarding the arrangement of series-parallel springs. The purpose of this experiment is to determine the spring constant for a series-parallel arrangement. This experiment was conducted with two independent variables, namely a series series 
on the spring and a parallel circuit on the spring. The author presents the tools and materials in detail, and the work procedures arranged based on each experiment also make it easier for students to carry out experiments. This experiment is not equipped with experimental images and observation tables.

In chapter 4 Fluid consists of 5 experiments. The first experiments the authors list on pages 77-78 regarding hydrostatic pressure. This experiment aims to understand the hydrostatic pressure in the fluid, the tools and materials used are very simple and easy to find, this experiment is also equipped with experimental drawings and systematic work procedures so that students can easily complete the experiments. Students are also asked to provide conclusions from the experiments that have been carried out.

The attempts of both authors list on page 85 of Archimedes' law. This experimental activity aims to observe Archimedes' law by observing the upward force (buoyancy) that is done by the fluid. The author lists the tools and materials with a numbering list. This activity emphasizes the investigative aspect and involves student skills related to the manipulative abilities of the student appropriate at the grade level. Students are given challenges to assemble tools and materials through work procedures, to make it easier for students to solve these challenges, the authors include illustrative images of the experiments to be carried out. After that students are required to provide conclusions from the results of the experiments that have been carried out.

The author's third experiment lists on pages $88-89$ regarding capillary action.

The purpose of conducting this experiment is to observe capillary events in water. The author's tools and materials include the numbering format, the author also provides an illustration of the experimental image and the work procedure presented in the form of systematic numbering will make it easier for students to complete the experiment. This experiment may be carried out during the learning process.

The fourth experiment the authors list on page 94 regarding Bernoulli's principle. The laboratory activities presented by the author aim to observe Bernoulli's principle in everyday life. This experiment is only carried out with a simple tool in the form of a sheet of paper, with illustrations and detailed work procedures that make it easy for students to complete the experiment. This experiment is very possible to do during class or when students study at home.

The fifth experiment the authors put on page 100 regarding the viscosity (viscosity) of a liquid. The aim of this experiment is to observe the viscosity properties of some fluids. The author's tools and materials include in detail with a list in the form of numbering. The author also includes a systematic work procedure, besides the existence of an observation table in this experiment will make it easier for students to retrieve data and process data.

Chapter 4 Temperature and Heat consists of 6 experiments. The first experiment the author lists on page 114 the coefficient of linear expansion. The author writes that the purpose of this experiment is to determine the coefficient of metal expansion. In this experiment, the author's tools and materials are detailed in the form of numbering. The work procedure is presented in a systematic and clear form, students are required to assemble the tools and materials independently, but the author helps facilitate the students by providing illustrations of a series of pictures of tools and materials that students must compile. This experiment was carried out several times taking data with different types of metals, unfortunately the author did not provide observation tables to make it easier for students to retrieve experimental data.

The author notes on pages 122-123 the drawing of the cooling graph of Napthalene (candles). This laboratory activity aims to observe changes in form, tools and materials the authors present in the form of a numbering list, the authors also include systematic work procedures and pictures of a series of tools and materials to make it easier for students to carry out laboratory activities. This activity can be carried out during class learning.

The author lists on pages 123-124 
regarding specific heat. The purpose of the specific heat experiment is to determine the specific heat of various materials, namely iron, aluminum and copper. The author includes tools and materials in the form of a list, work procedures are arranged coherently by the author to make it easier for students to carry out experiments. The author also gives questions at the end to make it easier for students to draw conclusions, but the author does not include an observation table.

The author lists a fourth experiment on page 127 regarding thermal conductivity. The author writes the purpose of this experimental activity is to compare the heat conductivity of several objects. The author's tools and materials are presented clearly through a numbering list, work procedures are also arranged systematically so that it will make it easier for students to carry out experiments, this experiment can be carried out directly in class.

The author lists on page 128 regarding heat transfer by convection. This experimental activity aims to observe heat flow by convection. The author writes the tools and materials and work procedures systematically to make it easier for students to experiment.

The author lists the sixth experiment on page 130 regarding the transfer of heat by radiation. The experimental activities presented by the author aim to observe heat transfer by radiation. The author writes the tools and materials and work procedures systematically to make it easier for students to experiment.

Chapter 5 The Kinetic Theory of Gases consists of 1 experiment. The author states on pages 141-141 of Boyle's Law, this experimental activity aims to observe everyday events that explain Boyle's law. The author writes the tools and materials clearly and the experimental procedure is detailed, the author also includes an experimental image that makes it easier for students to carry out investigations in order to obtain conclusions from the experiments that have been carried out.

Chapter 6 regarding the Law of Thermodynamics consists of 1 experiment. The author lists on page 164 regarding the First Law of Thermodynamics. In this experiment, the authors did not include the purpose, tools and materials and work procedures. The author uses the virtual laboratory to conduct experiments, the author only provides a link to access the virtual laboratory and includes questions that students must conclude after conducting the experiment.

Chapter 7 on Waves no experiment. Chapter 8 on Sound Waves contains 1 experiment. The author lists it on page 216 . The author does not write down the title and purpose of the experiment, the tools and materials and work procedures are arranged in paragraph form, making it difficult for students to carry out experiments, but the author writes questions at the end to make it easier for students to draw data conclusions, analyze and draw conclusions.

Chapter 9 Light Waves no experiment. Chapter 10 on Geometric Optics contains 1 experiment. The author lists on pages 287-288 about making a simple telescope. The author does not include the purpose of the experiment, but the author includes an overview of the implementation of the experiment. Tools and materials were prepared by the author with a numbering list format, experimental steps were arranged systematically and equipped with experimental pictures made it easier for students to carry out experiments and in chapter 11 on Global Warming there were no experiments.

In general, this book is included in the good category in terms of laboratory activities. Laboratory activities in this book are included in the very good category, meaning that in 21 experiments this aspect is of very good value, among others, these aspects are laboratory activities in accordance with the aspects of students' cognitive mastery, laboratory activities involve student skills, laboratory activities are safe for students, laboratory activities are appropriate. with the substance of the material displayed, laboratory activities are included in the description of the materials / materials displayed and aspects of laboratory activities in line with the description of the subject matter and are related to activity guidelines.

In terms of available tools and 
materials to support laboratory activities, this book gets a good category, because there is 1 experiment, namely in the experiment in chapter 6 regarding the Law of Thermodynamics 1 the author does not include tools and materials.

In the criteria for laboratory activities that emphasize the aspect of investigation, this book is categorized sufficient because there are 2 laboratory activities that emphasize this matter and for the category of laboratory activities which includes instructions for separate laboratory activities, this book also gets a very bad category because there is no separate activity manual, whereas in the STRS assessment by Collete \& Chiapetta (1994: 32) which suggests that each textbook should include a special book containing instructions for laboratory activities.

In the aspect of laboratory activities that can be carried out while the class is in progress, it gets a very bad category because there are three laboratory activities that cannot be carried out during class learning.

This book still has shortcomings, namely in the table section of experimental data that is not listed in all laboratory activities that the author presents, besides referring to the book entitled Physics Principles and Problems by A Glencoe program, it states that every laboratory activity should include a note or label about Safety Precautions the safety of laboratory activities that will be carried out, then in the book entitled Experiment in General Chemistry: Inquiry and Skill Building by Vickie Williamson and Larry Peck writes that inquiry-based laboratory activities have a pre-lab stage, namely the stages that are carried out before carrying out practicum activities, where students are given questions or questions related to experimental activities that will be carried out to see the initial abilities of students before carrying out practicum activities, then after laboratory activities have been carried out students are given a post-lab stage, where $\mathrm{p}$ Students will be asked questions or questions about laboratory activities that have been carried out, to see the abilities of students after carrying out laboratory activities or experiments, the two things from the reference book are not included in the laboratory activity sheet in this textbook.

Apart from these shortcomings, of course this book also has advantages, namely a complete section of objectives, a list of tools and materials, a picture of a series of experiments, a work procedure that the author presents in detail as well as questions and assignments that can make it easier for students to carry out experiments, analyze data and draw conclusions from each trial.

\section{Conclusion}

Based on the results of research and discussion, it can be concluded that the high school physics textbook class XI 2013 curriculum by Bambang Ruwanto has a level of conformity based on the criteria that refer to STRS, especially in aspects of laboratory activities of $78 \%$, and high school physics textbook class XI curriculum 2013 Bambang Ruwanto's works are of good quality (B) based on the criteria that refer to the STRS, especially in the laboratory aspect.

\section{Reference}

Collete A. T \& Chiapetta E. L. (1994). Science Introduction in The Middle and Secondary Schools. New York: Macmillan Publishing

Depdiknas. (2005). Peraturan Menteri Pendidikan Nasional Republik Indonesia No 11 Tahun 2005 tentang Buku Teks Pelajaran. In Departemen Pendidikan Nasional

Glencoe. (2004). Physics Principles and Problems. The McGraw-Hill Compnis. Columbus

Greene dan Petty. (1981). Developing Language Skill in The Elementary Schools. Boston: Alyn and Bacon Inc

Ika Lestari. (2013). Pengembangan Bahan Ajar Berbasis Kompetensi. Jakarta: Akademia Permata.

Karumaningrum, Septiana. (2017). Perbandingan Kualitas BSE dan NonBSE pada Mata Pelajaran Fisika SMA Kelas X: Telaah Menggunakan Instrumen STRS. Fakultas Matematika dan Ilmu Pengetahuan Alam. Yogyakarta. Universitas Negeri Yogyakarta

Masnur Muslich. (2010). Textbook Writing: 
Dasar-dasar Pemahaman, Penulisan dan Pemakaian Buku Teks. Jogjakarta: Ar-Ruzz

Ruwanto, Bambang. (2017). Fisika 2 SMA Kelas XI. Jakarta: Yudhistira

Satiti,Asri. (2019). Analisis Kualitas Buku Teks Mata Pelajaran Fisika Untuk SMA Kelas XI Dengan Menggunakan
Instrumen STRS. Fakultas Matematika dan Ilmu Pengetahuan Alam. Yogyakarta. Universitas Negeri Yogyakarta

Williamson, Vickie dan Larry Peck. (2009). Eksperiment in General Chemistry : Inquiry and Skill Building. Brooks/Cole. Cengage Learning. 